\title{
Davenant's The Siege of Rhodes: Islam, Heroism and Solyman the Magnificent
}

\author{
Samia AL-Shayban \\ King Saud University, Riyadh, Saudi Arabia
}

\begin{abstract}
This study is concerned with William Davenant's dramatization of Solyman the Magnificent as an ideal man of war and peace. The structure of the play and characters are designed to reveal Solyman's honorable character. In the introduction, the author reviews the critical history of The Siege of Rhodes (1661). The section “The Siege” is concerned with the Sultan's attitude to war and his behavior towards his foes, which is marked by ambition and valor. In the section "Victory”, the author traces Solyman's generosity and mercy towards the defeated Rhodians. Ianthe and Alphonso dominate the "Characters" sections, which reveal how both characters play a central role in stressing Solyman's honorable conduct in war and peace. The dramatic centre of the play, as highlighted by the author, is Solyman's honorable character. With such dramatization Davenant departs from the conventional presentation of Turks as moral and political transgressors.
\end{abstract}

Keywords: William Davenant, Solyman the Magnificent, Turks, knights of Rhodes

\section{Introduction}

"Critical readings have neglected the play as a piece of drama and overlooked the interrelated significance of the image of the Turk that lies at its heart” (Birchwood, 2007, p. 104).

In spite of the fact that Birchwood acknowledges the play's need for a dramatic reading, he himself refrains from undertaking the task. The reading he offers does not touch the play's dramaturgy, but instead considers its relationship with contemporary issues and with Davenant's accusations of apostasy (Birchwood, 2007, p. 104). Offering a different perspective, in his classic study of English Restoration drama, Hughes (1996, pp. 1-77) studied the pioneering theatricality of the play. Clare (2006, pp. 181-184) paid critical attention to the heroic love story between Ianthe and her husband, the Sicilian Duke Alphonso, whom she also considered as the protagonists of the play. However, Chew (1965, p. 496) believed that The Siege of Rhodes (1661) was not worth reading as a dramatic experience, although it is not clear whether Chew's judgment is based on the original version of 1656 which was composed as an opera. After the restoration of 1660, Davenant revised the operatic version and turned it into a drama, adding a new part. By 1661, he staged The Siege of Rhodes as a drama in two parts at the Duke's Playhouse. It is noticeable that the available critical studies do not examine the dramatic function of the Turks as represented by Solyman the Magnificent. Therefore, this study is an attempt to reread The Siege of Rhodes through proposing the dramatic centrality of the Turkish Sultan. His centrality is traced through two elements: the structure of the play and the main characters on the Christian side, Ianthe and Alphonso. Both elements are designed to celebrate the Turkish Sultan as an ideal man of war and peace.

Samia AL-Shayban, assistant professor, Department of English, King Saud University. 


\section{Structure}

\section{The Siege}

The structure of the play Davenant employs to stress Solyman's idealism is in two parts: the siege and the victory. During the siege of Rhodes, Solyman displays the conventional qualities of a heroic hero-ambition and valor. Solyman's attack and subsequent siege of "rocky" Rhodes in an attempt to subdue the island is the best testimony of his ambition. The island is the home of the knights of Rhodes who have a military history that started with the first crusade to Jerusalem in the 11th century. The knights not only enjoyed a long experience in affairs of war but were reputed to be fierce and brave warriors (Giertz, 2010). During their two hundred years in Rhodes, which they captured from the Byzantine emperor, Andronicus, they sustained and overcame several serious attacks and sieges. In 1479 and 1480, the Turks' expeditions to the island proved costly and futile as the knights forced them to retreat (Brockman, 1971). To attempt another assault against the island and undertake such a dangerous task proves Solyman to be an ambitious emperor who desires to succeed where others failed. The Admiral of Rhodes describes the fleet:

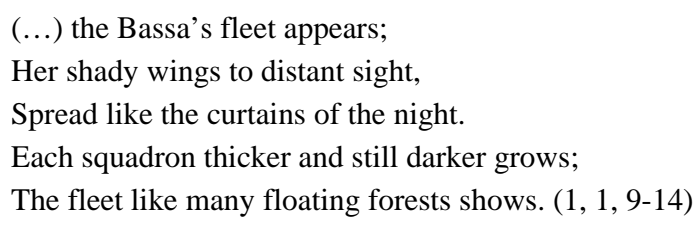

The enormous size of the fleet reveals Solyman's ambition to win this war against the knights of Rhodes. It also reveals that the ambitious emperor takes his foes seriously. The experienced Admiral's metaphoric description of the enormous fleet foretells the difficulties the contending powerful parties will face. As the task of capturing Rhodes proves difficult, Solyman expresses his determination to succeed. When his vizier Pyrrhus explains that the task the Turkish army is facing under the fortified walls of Rhodes is extremely difficult and dangerous, the Sultan reminds him of ants' slow but assured labor. Ants face high hills "rais'd, in scorn/of labour, to be levell'd with a spurn" (2, 2, 74-76). The Sultan insists on being as patient and determined as the ants. This is clear through his plan to build a castle upon Philermus Hill that overlooks Rhodes. The Sultan explains his new tactics, as Grecians from Lycia will:

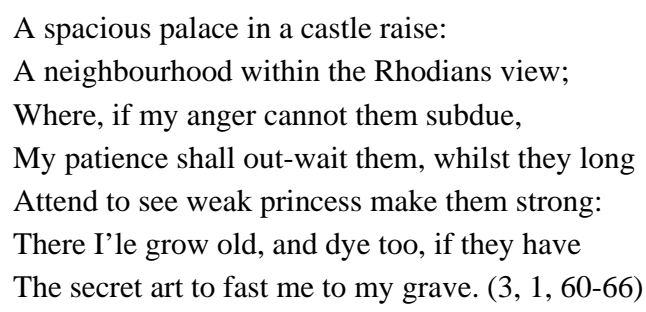

To the ambitious Sultan, abandoning the siege is not an option. As a result, patience seems to be the only suitable tactic. He insists that he is ready to spend his lifetime besieging Rhodes. Thus, building a castle overlooking the town is a practical evidence of his determination.

The other quality Solyman displays during the siege is valor. To him, it is a philosophical notion that he deeply understands, possesses, and appreciates. Solyman's philosophical concept of valor can be perceived through his argument with his general over their failure to capture the town. He rebukes Pyrrhus, his General: 
What sudden halt hath stay'd thy

swift renown, if, when old,

O’re-running kingdoms, stopping at a town?

courage cools because thy blood is cold. $(2,1,60-61,67-68)$

Solyman argues that bravery is a state of mind that transcends age and physical strength. Thus, an old man who is no longer physically fit but possesses mental bravery can emerge victorious. The fact that his aging General fails to capture a small town is an indicator of his dispossession of mental valor. The same philosophical concept motivates him to declare, "The valiant man is his own emperor" $(4,1,18)$. As a state of mind, bravery enables those who possess it to enjoy a strong sense of independence that resists submission to power and fear of danger. To the emperor, bravery is not only a philosophy but also a way of life. His personal bravery can be perceived through his leadership of the dangerous expedition against such formidable opponents as the knights of Rhodes. When after three months of fierce fighting, Solyman manages to land on Rhodes, the chorus announces the news:

Great Solyman is landed now;

All fate he seems to be;

And brings those tempests in his brow

Which he deserv'd at sea. (2, 1, 47-50)

The fact that Solyman succeeds in breaking the defenses of the island and landing is a testimony to his bravery. The chorus connects him to fate in the sense that he is decisive and brave in executing his will. The Sultan's involvement in war goes beyond his leadership to include physical participation in the fight. The instructions he gives to Pyrrhus, his General, reveal this:

Pyrrhus, draw up our army wide!

Then from the gross two strong reserves divide

And spread the wings

Bring thou the rear, we lead the van. $(3,1,1-3,12)$

Solyman's decision to head the van proves his insistence on sharing the dangers his men are facing in the battlefield. Furthermore, it reveals that, due to constant involvement, the Sultan is well practiced in the tactics of war. To give further credibility to the Sultan's valor, Davenant employs his foe, Villerius, the Grand Master of the knights of Rhodes. He describes their experience in fighting Solyman:

The foe three moons tempestuously has spent

Where we will never yield, nor he relent;

Still we but raise what must be beaten down. (2, 1, 7-9)

The Master of Rhodes testifies that Solyman is more than their match in bravery. He also confirms that, due to his bravery, his victory is guaranteed. Being a brave man, Solyman cannot but appreciate those who display it. Thus, he holds in high esteem the bravery of the knights of Rhodes and Ianthe the Sicilian princess. When his army's assault against the town fails, Solyman recognizes the bravery of the knights who are defending it. He says:

In honor's orb the Christians shine;

Their light in war does still increase;

Thus vildly they dare live, and yet dare dye. (2, 1, 95-96, 103) 
To the emperor, his army's failure is the result of the foe's bravery and readiness to die defending their island. The Sicilian princess, Ianthe, proves to be no less brave and, thus, deserves the Sultan's respect. The princess, who is the "Bride to Alphonso, who in Rhodes so long/The team has been of each heroic song", has been captured while trying to reach her husband in besieged Rhodes (11, 1, 132-133). Mustapha explains that the princess, "for [her husband] relief those gallies fraught;/Both stow'd with what her dow'r and jewels brought” (11, 1, 134-135). Not only does the princess fill her ships with supplies but also she and her companions "maintain'd a bloody fight" $(2,1,118-120,122)$. When captured by the Turks, the princess displays bravery by refusing the Sultan's orders to unveil. She informs the Sultan, "This curtain only opens to [her lord's] eyes" $(2,1,145)$. She also demands to be conducted to her husband, "To take my share of all his destiny" $(2,1,153)$. In case of her request being refused, she assures the Sultan that she will commit suicide where "in death cold arms/My honour instant safety give" (2, 1, 156-157). The Sultan finds it difficult not to admire the princess' bravery and virtue:

O wond'rous vertue of Christian wife!

Advent'ring life support, then her life

To save her ruin'd lord. (2, 1, 136-138)

The princess has loaded the ships with supplies to deliver to Rhodes. By doing so, she risks not only her resources but, most importantly, her life. As a practical gesture of respect and admiration, the Sultan informs Ianthe:

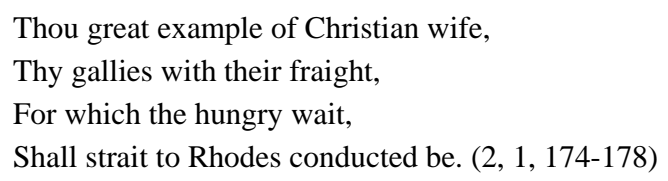

The princess is allowed to land in Rhodes with all the supplies she has brought. Furthermore, the Sultan gives his permission that Ianthe and her husband can depart from besieged Rhodes to safe Sicily. He informs her “... as thy passage to him shall be free,/So both may safe return to Sicilie” (2, 2, 179-180).

\section{Victory}

As a victorious warrior, Solyman maintains his ideal morals. In dealing with the defeated Rhodes, he displays generosity and mercy. Solyman's generosity can be perceived through his response to the Rhodians' request for a peace treaty and to Ianthe who visits to negotiate its terms. Usually, victorious leaders are particularly vindictive towards the foe who displays lengthy and brave resistance. The Grand Master of Rhodes, Villerius, warns his knights that the Turks will be enraged and ill-mannered when they besiege the city. He even advises them that "All those attempts of valor we must shun/which may the Sultan vex..." $(1,1,146-147)$. Throughout the siege, the knights of Rhodes display an outstanding bravery that delays Solyman's capture of the island. However, the victorious Solyman proves that the Grand Master's fear is groundless. His General informs him that "Rhodes has hung a flag of treaty out" $(2,1,1)$. Responding to the news, he says:

Thy courage, haughty Rhodes, Is but a braver kind of impudence.

Thou knew'st my strength, but thou didst better

Know

How much I priz'd the braveryof a foe. (2, 1, 3-8) 
In Solyman's response, there is no sense of elation or pride, but quiet recognition of his achievements and that of his foes. He expresses his respect for their bravery and strong sense of honour. In spite of their awareness of Solyman's superior power and their unavoidable defeat, they have chosen to make his task difficult. Such conduct motivates the Sultan to consider them his equal in bravery and determination. He explains their desire to end the war:

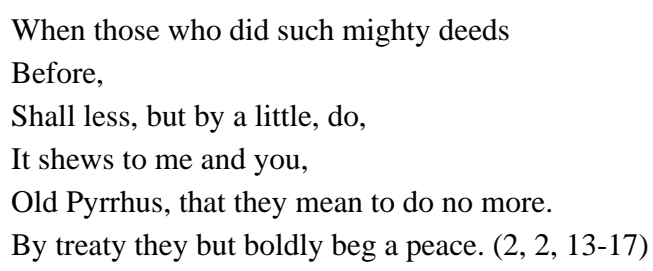

The emperor argues that the Rhodians' desire to end the war is not motivated by weakness but by a genuine desire for peace. He knows that they have the ability to continue the war but they choose to end it.

The knights are not the only ones who deserve the Sultan's respect. Ianthe is treated with generosity. Mustapha informs his Sultan that: "Villerius sends his homage to your feet" and "Ianthe will be here to kneel and treat":

The emperor responds:

(...) Mustapha, let her reception be

As great as is the faith she has in me. (2, 2, 41-42)

To understand the moral significance of such instructions, we need to be aware of Ianthe's stand in the strategy of this war. Unlike the knights who have qualified for Solyman's generosity, Ianthe is in a difficult position. The roots of her difficult position can be traced to her previous encounter with the Sultan, when Ianthe was captured trying to give aid to the besieged island and her husband, Alphonso, the Duke of Sicily. She has been freed, allowed to join her husband and given the chance to depart from the island along with her husband. However, the offer is rejected and Ianthe joins the side of the emperor's foes. He wonders at her presence:

What wandering star does lead her forth? Can she

Who scorn'd a passport for her liberty,

Vouchsafe to come, and treat without it now? (2, 2, 27-29)

The fact that Ianthe feels safe enough to meet him again and ask for what she has previously rejected is an undeniable sign of her faith in him as a reliable and honorable man. Solyman judges that Ianthe's trust in him deserves the great reception she receives.

The other moral quality Solyman reveals as a victorious emperor is mercy. The mercy he displays is of particular significance as it targets his defeated foes who betray his trust. Solyman preserves the life and honour of his enemies, the knights of Rhodes and their ally Alphono, Duke of Sicily. The knights and the Duke are under an obligation to respect their peace deal with the Turks while Ianthe is negotiating the treaty terms. However, suspecting that Ianthe's honor is in danger they fail to respect the Sultan or the deal and launch a bloody assault against the Turkish camp. Pyrrhus informs the Sultan that the Rhodians, "their flag of treaty... have taken in". Alphonso and Villerius attack with two thousand Rhodian knights. However, the assault fails and the Grand Master Villerius laments: 
E're morning does advance we must retire;

Justly asham'd to let the days great light

Shew what a little we have done to night. $(5,4,2-4)$

The Grand Master makes it clear that they have done very little. This testimony from the master is significant. It reveals that the Turkish army performance has been outstanding, and it allows the knights no option but to retreat.

Despite the knights' apparent military and moral defeat, the Sultan refuses to kill them. He informs Pyrrhus:

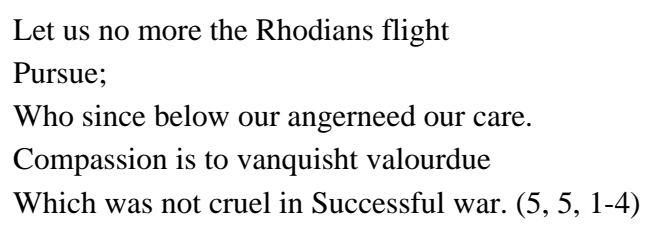

To the victorious Sultan, the defeated knights need compassion and not punishment. To him, compassion towards the enemy is a testimony of one's "valor”. The furious Pyrrhus disagrees with the Sultan and argues:

The world is wicked grown, and wicked men

Are but enabled to offend agen,

When they are pardon'd and left arm'd. (5, 5, 9-11)

Pyrrhus' argument is meant to remind the Sultan of the knights' treachery and their inability to honor the terms that they proposed. Considering their behavior, Pyrrhus judges that they are likely to launch another assault if they are not punished effectively. He insists that they do not deserve such generous treatment. However, he explains that the exceptional moral stand from the Sultan towards his treacherous foes is rooted in divinity. He explains:

Our Sultan does his pow'r from

Heav'n derive,

'Tis rais'd above the reach of human force:

It could not else with soft compassion thrive. (5, 5, 5-7)

To Pyrrhus, Sultan's honorable dealing with his foes is beyond human behavior. As such it is located within the scope of divine norms. Significantly, the knights of Rhodes are not the only ones whose lives the Sultan preserves. The Duke of Sicily, Alphonso, who has played a crucial role in the assault against the Turks, has been saved and freed by orders from the Sultan. The Duke has played a crucial role in delaying the fall of the city. Mustapha, the Turkish General, informs the Sultan of Alphonso's heroism in defending Rhodes against their attacks. Alphonso is the one:

$$
\begin{aligned}
& \text {... who in Rhodes so long } \\
& \text { The team has been of each heroic song; }(2,1,132-133)
\end{aligned}
$$

The brave Duke has been captured during his last attempt against the Turks. Mustapha confirms the identity of the prisoner:

The pris'ner whom in doubtfull fight

We took,

Is young Alphonso, the Sicilian Duke. (5, 5, 17-20) 
To such news the Sultan expresses his delight and insists that, Fortunes could never find if she had

Eyes,

A present for me which I more would prize. (5, 5, 21-23)

With such response, one would expect Solyman to punish the Duke for attacking his camp in the middle of treaty negotiations or indeed for his role in delaying the capturing of the island. However, the Sultan informs his prisoner:

You may imbark for the Sicilian coast,

And there possess your wife when Rhodes is lost. (5, 6, 184-185)

The Sultan saves the Duke's life, restores his freedom and love. Furthermore, he exempts him, along with his wife, Ianthe, from sharing the tragic fate of Rhodes, as they are allowed to depart to Sicily.

Besides preserving the lives of his foes, the Sultan enables them to maintain an honorable stand. When Solyman informs Alphonso that he can depart to Sicily, the Duke responds:

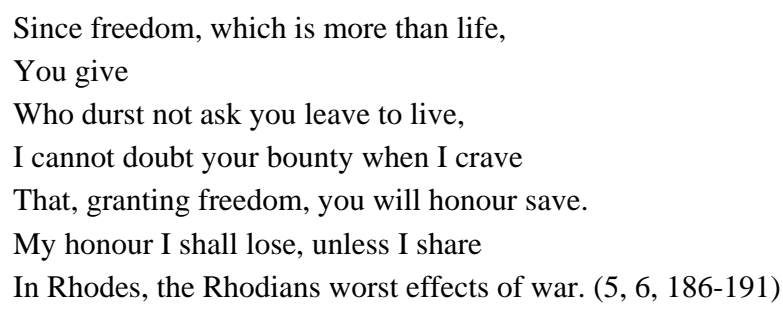

The Duke makes it clear that he would lose his honor if he were to abandon Rhodes and depart to Sicily. He asks the Sultan to save his honor by allowing him to go back to Rhodes and share its fate with the people. The Sultan grants him the wish and allows him to depart to Rhodes along with his wife, Ianthe. He states that "Both may to Rhodes return". Alphonso is not the only one whose honor has been saved by the Sultan. The knights of Rhodes receive similar generous treatment. He allows Ianthe, "who nobly did [his] honor trust", to decide the terms of the treaty for Rhodes. He says:

Go back, Ianthe; make your own

Conditions boldly for the town. (5, 4, 208-209)

Ianthe is allowed to go back to Rhodes to decide the terms of the treaty. Through Ianthe, the Sultan gives the knights of Rhodes the chance to dictate their own terms and enjoy an honorable end to the long and bloody war.

\section{Characters}

\section{Ianthe}

To further stress Solyman's ideal moral stand, Davenant allows him to be judged by his Christian foes, Ianthe and her husband, Duke Alphonso. By doing this, Davenant creates an objective dramatic space between the emperor and the audience. This space gives the audience the chance to perceive the Sultan not through his person or the view of his friends, but most importantly through the judgment of his foes. Ianthe and Alphonso, however, highlight Solyman's ideal character in different ways. Throughout the play, Ianthe displays fierce and firm belief in the Sultan's honor. On the other hand, Alphonso maintains a hostile attitude towards the Sultan, only to change at the end of the play. Conventionally, Turkish Sultans are staged as political tyrants and sexual 
transgressors (Birchwood, 2007, pp. 69-128). By choosing a beautiful Christian princess to defend Solyman's honor, Davenant makes it clear that he is opposing the negative conventional presentation of the Turks. Significantly, Ianthe's mission proves to be far from easy. After her first encounter with Solyman, Ianthe finds herself expressing an opinion opposed by many. She tells her husband that there is no ground for "All that of Turks and Tyrants I had heard” (3, 2, 163). She gives a more elaborate picture of his virtuous and generous treatment. She states that:

He seem'd in civil France, and monarch there:

For soon my person, gallies, fraight, were free By his command. (3, 2, 168-169)

Ianthe appreciates his chivalrous treatment as he allows her and her ships to pass his army and go to Rhodes to join her husband, who happens to be his foe. To her, the Sultan is no different from the refined and chivalrous French monarchs. With such comparison, she closes the moral distance that the Europeans usually construct to separate and distinguish themselves from their enemies, the Turks. By venturing such an unusual attitude, Ianthe opposes not only the dominant views of the Turks, but also that of her husband. Adamant in her belief in the Sultan, Ianthe finds herself defending him against the ill opinion of her husband. When Alphonso calls him “faithless Solyman” $(4,1,70)$, she responds:

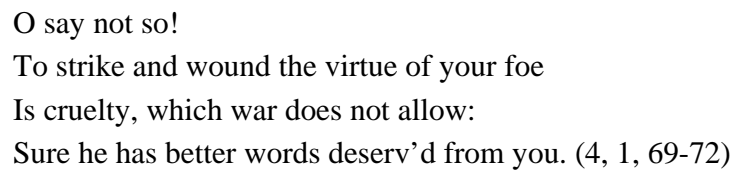

When her husband expresses his surprise and suspicion of her zealous defense of the Sultan's virtue, she remains firm in her opinion and tells her husband that the Sultan “... though a foe, is generous and true”.

\section{Alphonso}

Like Ianthe, Alphonso plays a crucial role in stressing the moral merits of Solyman. However, Davenant follows a different technique by allowing Alphonso to change his attitude from that of a foe to a friend of the Sultan. In harmony with the conventional attitude of the time to the Muslim Turks, Alphonso rejects the Sultan's faith and denies him any possession of honor. When Solyman attacks Rhodes, Alphonso, who has been visiting, is advised to depart to his bride in Sicily. The Grand Master explains that, "we love to lodge, not to entombe a guest” $(1,1,71)$. To that he answers:

Here for my tomb or triumph I will stay.

My sword against proud Solyman I draw,

His cursed prophet, and his sensual law. $(1,1,82-84)$

Alphonso makes it clear that his fight against Solyman is for religious reasons. By cursing Solyman's prophet and his laws, Alphonso denies Islam any validity and makes himself the enemy of the Muslim Sultan. Since, to Alphonso, Islam is invalid as a religion, he cannot allow it to be connected to Providence. Ianthe explains to him that Providence sends Solyman to deliver them from the war-weary Rhodes to the safety of Sicily. To that he responds:

Had Heav'n that pass-port for our free-

Dom sent,

It would have chose some better instrument

Than faithless Solyman. (4, 1, 67-70) 
When he finds himself was forced to acknowledge the Sultan's generous behavior towards his wife, he comments, "This Christian Turk amazes me" $(3,3,178)$. The fact that he calls him Christian Turk reflects Alphonso's inability to connect Islam with any honorable and virtuous behavior. This attitude becomes more explicit when he suspects that his wife must have compromised her virtue to receive chivalrous treatment from the Sultan. In response to Ianthe's acknowledgement of the Sultan's honorable dealings with her, he responds:

He in two days your high esteem has

Won:

What he would do I know; who knows what

He has done? (4, 1, 81-83)

In spite of the fact that Ianthe is well known for her virtue as well as her love for Alphonso, his inability to expect honorable actions from the Sultan motivates him to question his wife's behavior (Mcjannet, 2009, pp. 183-193). Significantly, Alphonso's hostility towards Solyman ends when he personally experiences the Sultan's generosity. As a prisoner in the Turkish camp after the failed attack, he constructs, "Alphonso is pardoned and freed". The Sultan rebukes him for his distrust and informs him:

You may imbark for the Sicilian coast,

And there possess your wife when Rhodes is lost. (5, 4, 184-185)

Touched by Solyman's behavior, the friendship Alphonso rejects for so long becomes a fitting end for their encounter. He assures the Sultan:

To Rhodes I go,

To be in Rhodes your suppliant, not your foe. $(5,4,194-195)$

Indeed, Solyman's honorable deeds, which Alphonso once believed to be "strange above miracle”, prove to be a reality.

\section{Conclusions}

Solyman's miraculous stand is at the dramatic and moral heart of the play. The Muslim Sultan displays honorable qualities that can be recognized and appreciated by friends and foes. Such approach is of dramatic and ideological significance. Davenant opposed the conventional heritage of the British theatre that dramatizes Muslim Turks as political and moral transgressors. Thus, to allow Ianthe, the Sicilian Princess to be one of the Sultan's most ardent defenders is not a coincidence. Davenant is deliberately dramatizing Solyman in particular and Muslim Turks in general under favorable light. In a sign of further endorsement of Solyman's virtuous stand, Davenant secures the support of his strong opponent, Alphonso. After long and vicious hostility, the Sicilian Duke joins his voice to that of his wife, Ianthe, and recognizes Solyman's moral merits. Such departure from the conventional dramatization of Turks can be explained in connection with the restored theatre in 1660 England. The audience of the Restoration era desired unusual elements to be displayed on the stage. It can also be read as a change of priorities: The Catholic Spanish and not the Muslim Turks, are the enemies of England. Thus, by championing the Muslims, the classical enemies of the Spaniards, Davenant is in fact undermining Spain along with its religious and political ideologies. 


\section{References}

Birchwood, M. (2007). Staging Islam in England: Drama and culture, 1640-1685. Cambridge: D.S. Brewer.

Bradford, E. (2012). The shield and the sword: The knights of St. John, Jerusalem, Rhodes and Malta. E-reads.

Brockman, E. (1971). The two sieges of Rhodes, 1480-1522. London: Transatlantic Arts.

Chew, S. C. (1965). The crescent and the rose: Islam and England during the Renaissance. London: Octagon Books.

Clare , J. (2006). Drama of the English Republic, 1649-1660. Manchester: Manchester University Press.

Fuchs, B. (2000). Faithless empires: Renegades and the English nation. ELH, 67, 45-69.

Giertz, B. (2010). The knights of Rhodes. (B. Erickson Trans.). Canada: Resource Publication.

Hughes, D. (1996). English drama, 1660-1700. Oxford: Clarendon Press.

Matar, N. (1998). Islam in Britain, 1558-1685. Cambridge: Cambridge University Press.

Mcjannet, L. (2009). Islam and English drama: A critical history. Early Theatre, 12, 183-193.

Stumoulis, M. L. (2008). Knights in Rhodes. Maryland: Publish America. 